\title{
Coaching in the professional and personal development of nurses
}

Coaching w rozwoju zawodowym i osobistym pielęgniarek

\section{Alicja Diak1, Joanna Sułkowska², Ilona Kuźmicz², Iwona Malinowska-Lipień2, Agnieszka Gniadek', Tomasz Brzostek²}

'Department of Nursing Management and Epidemiological Nursing, Faculty of Health Sciences, Jagiellonian University Medical College, Poland 2Department of Internal Medicine and Community Nursing, Faculty of Health Sciences, Jagiellonian University Medical College, Poland

Wprowadzenie. Deficyt pielęgniarek obserwowany w UE (Unii Europejskiej) może mieć różne przyczyny m. in.: mało atrakcyjne warunki pracy, niepodejmowanie pracy w tej profesji (pomimo posiadanego wykształcenia) oraz wysoki wskaźnik wypalenia zawodowego. Wyzwaniem dla pracodawców oraz instytucji zajmujących się problemami współczesnego pielęgniarstwa pozostaje problem zachęcenia adeptów kierunku do podjęcia pracy w zawodzie i pozostania w nim na dłużej. Także duże znaczenie ma nauczenie pielęgniarek jak chronić się przed wypaleniem zawodowym, łączyć ambicje zawodowe z potrzebami rodziny a przede wszystkim osobistą satysfakcją z życia. Pośród potencjalnych rozwiązań wspomagających świadome zaplanowanie życia osobistego i dalszego rozwoju zawodowego, warto rozważyć wsparcie coacha, podobnie jak to ma miejsce w innych zawodach.

Cel. Analiza sytuacji zawodowej pielęgniarek w kontekście potrzeby indywidualnego rozwoju z zastosowaniem metody coachingu. Metodyka. Zastosowano metodę analizy i krytyki piśmiennictwa naukowego.

Podsumowanie i wnioski. Wykorzystanie elementów coachingu stwarza szansę, by pielęgniarka/pielęgniarz w sposób świadomy i planowy projektowali przebieg swojego rozwoju zawodowego synchronicznie z potrzebami i oczekiwaniami w życiu osobistym, rodzinnym i społecznym. Dodatkowymi korzyściami z zastosowania tej formy wsparcia są umiejętność lepszego radzenia sobie ze stresem, zachowanie równowagi pomiędzy pracą a życiem osobistym (tzw. work-life balance) oraz prewencja wypalenia zawodowego. coaching, rozwój zawodowy, pielęgniarka, pielęgniarz

Introduction. Shortage of nurses reported in the EU (European Union) among other causes is related to: non-attractive work conditions, lack of willingness to take up job as a nurse (despite their education), and high risk of professional burnout. Encouraging graduates to take up a job in the profession and remain is a challenge for employers and institutions involved in the problems of modern nursing. Teaching nurses how to: protect themselves from professional burnout, how to combine career ambitions, family needs and above all personal satisfaction is of utmost importance. Amongst possible solutions which enhance planning of career and personal development in a deliberate manner, as is the case in other professions, it may be worth considering the support of a coach. Aim. Analysis of the professional situation of nurses in the context of need for individual development using the coaching method. Method. A method of analysis and criticism of the literature was used.

Conclusions and results. Coaching gives an opportunity for conscious planning process of nurse professional development in synchrony with needs and expectations for personal, family and social life. Better stress management, maintaining work-life balance and professional burnout prevention are benefits provided by this approach. 


\section{INTRODUCTION}

Nursing profession includes providing different health-related services, among others: recognizing patient's health condition and needs; planning and taking care of the patient; preventive, diagnostic, therapeutic, rehabilitation and medical rescue professional activities. The nurse's tasks also encompass: execution of medical orders in the process of diagnosis, treatment, and rehabilitation [1]. Nurses closely collaborate with other members of the multidisciplinary therapeutic team including: physicians, midwives, physiotherapists, dieticians, psychologists and pedagogues. Nurses actively participate in diagnostic, therapeutic, patient's care and rehabilitation processes. Cooperation with patients and their families who presented differentiated behaviour style and expectations level, which sometimes are beyond the reach of the country's healthcare system, belong to everyday work situations. Nurses are often the first professionals in whom patients are looking for understanding, help, advice and support. At the same time, they are exposed to various types of frustration, aggression [2] or even mobbing [3]. As a consequence, they experience emotions which have different direction and intensity. During recent years nursing education has been substantially modified which has allowed acquiring highly specialised knowledge, skills and attitudes. Nevertheless, the importance of choosing the workplace and/or modify conditions to control work stress [4] and reduce burnout level are crucial for achieving satisfaction in professional and personal life [5-7].

Coaching is one of a few solutions introduced to enhance deliberative professional development creation [8-11] and may be beneficial for students, graduates and working nurses. This approach is a form of support for people who want to reach their full potential, establish goals and ways of attaining them, as well as to strengthen their knowledge and skills [12].

\section{AIM}

Introducing coaching in making decisions about nurses' professional and personal development in a deliberate manner.

\section{Professional development in context of workload and satisfaction level amongst nursing stuff}

The term professional development is used in reference to progress against the current state of affairs and is related to a specific change within a set time period [13]. It means also "a lifelong process encompassing all the developmental aspects of a human being that can be related to work" [14].

Professional development functions include: " $1 /$ expanding knowledge useful in problem situation, especially in conceptual work; 2 / learning based on experience - acquisition of practical knowledge through observation of oneself and other employees, and implementation of new solutions at work; 3 / new attitudes and beliefs development, implying a change of existing views, reformulating system of values, principles and standards of conduct; 4 / the possibility of rebuilding professional qualifications concerning the personal dimension and referring to the personal competences of a given employee, their diagnosis and improvement; 5/ collaborating and contributing to staff development as regards knowledge and skills sharing, the knowledge resources of other employees using, mutual learning and interaction (coaching, mentoring)" [15].

As in the most EU countries, in Poland nurses' education has been conducted at universities and vocational schools of higher education (public and non-public) since 1998. Nurses are obligated to lifelong learning according to the Act on Profession of Nurse and Midwife [2] and provisions of the European Federation of Nurses Associations [16]. They could continue their professional development by attending specialist training sessions, specialized and qualifying courses based on education programmes - approved by the Minister of Health which would finally lead to obtaining a nursing specialist title [17]. Other forms of development are accessible through completing master's, post-graduate and doctoral studies as well as further academic careers.

Regardless of this above presented optimistic career picture, the current situation in Poland presents unfavorable trend. Some graduates do not take up employment as a nurse [18], increasing percentage is leaving the profession and growing economic migration is observed [19-21].

Nursing shortage does not only concern Polish hospitals, but it applies to the whole of Europe. This deficit leads to the increase in adverse events and even greater work overload amongst nursing staff. The results from the European Union 7th Framework Programme RN4CAST unambiguously demonstrate that the increase in the number of nursing staff results in lower number of patients' deaths [22-23]. Results of the research programme indicate that the measures of psychological well-being (such as: job dissatisfaction, job evaluation and rewarding, professional satisfaction, possibility of further development and promotion) are strongly connected to the intent to leave the job and represent the main determinant for such decisions [24]. These recently mentioned conclusions were brought by earlier research conducted by International Research Programme known as European NEXT Study [19].

The assessment of job satisfaction is based on a number of factors, including the atmosphere at a workplace, the rapport with employees, and the level of salary [25]. The research conducted by Wysokiński et al. shows that a lack of job satisfaction is declared by as many as approximately $50 \%$ of nurses in Poland. The authors underline that these data are consistent with the results of other researchers: $41 \%$ in the United States, 38\% in Scotland, 36\% in England, 33\% in Canada and 17\% in Germany [25]. Salary dissatisfaction is a factor that leads to a decrease in the satisfaction level within the study group [26]. Irrespective of the salary level, as indicated by the research on nurses employed in psychiatric wards, the lack of job satisfaction present in $37 \%$ of the respondents stems from the high levels of both mental and physical stress [25]. As a consequence, fatigue could occur, which - once it 
becomes chronic in nature - may lead to depression, decreased levels of professional satisfaction and deterioration in healthcare quality [27]. Work overload is one of the factors contributing to the development of professional burnout - which according to Nowakowska et al. - is present in 1/3 from 405 nurses who took part in the research [28]. Results of the international RN4CAST project indicated that roughly $30 \%$ of nurses working in European hospitals had high scores in Maslach Burnout Inventory [29], it is worth mentioning that the burnout is one of the predictors of premature leaving the profession [24].

As a consequence, it may be assumed that the nursing shortage is determined by unsatisfactory earnings on the one hand, and by the atmosphere and workplace expectations on the other [20]. While the level of salary is on the part of the legislator and the administrators of the healthcare system, the consistency between the employment conditions and the employees' expectations, as well as the active cooperation of both parties for improvement and harmonious development, lie within the plane of interaction amongst the management stuff, the team and the employee (and hence they are potentially negotiable). It is within the realm of coaching also to positively support this process [30-33].

Providing employees with an opportunity to make autonomous decisions concerning their development greatly determines their job satisfaction level and willingness to perform the job with commitment and passion [34]. However, despite the final satisfaction from the enhancement of professional qualifications, as indicated by Graf et al. [35], an excessive burden resulting from current work overload (sometimes working on two and more posts) and simultaneous commitment to studies, high costs of education, and indirect financial constraints are important limiting factors for nurses' professional development [36].

The above-mentioned characteristics of nurses' workload are potential arguments to consider coaching for supporting nurses from the early stages of the education, in the hope that this process will improve the professional formation in terms of social competences, active participation in the workplace, and job satisfaction. As a result, it may also promote taking up a nurse job by graduates, improve professional retainment and, in the long run, encourage young people to study, and seek their career in this profession [9-10,37-38].

\section{Coaching and its role in the context of professional and personal development}

According to the definition proposed by the International Coaching Federation (ICF) and the rules included in the ICF Code of Ethics, coaching is a process based on a partner relation built between the participant (the coachee) and the person who conducts (the coach). The purpose of this process is to support the development and improve the results of the actions taken by the participant. The participation in this process is often preceded by the so-called preliminary session, during which the coach explains what exactly coaching means and what results can be expected by the participant. The next stage involves determining cooperation principles and the goal which the coachee is willing to work on. It is important that this goal is defined by the person interested in a precise, realistic and measurable manner. Even though the coaching process arises out of the interaction between the parties, the responsibility for the effects and changes made is on the part of the participant, which, in turn, leads to his/her self-empowerment. During the coaching process, there is no room for advice-giving or offering ready-made solutions by the coach. The coach supervises the entire process, by attentive listening to the participant and asking open-ended questions which are intended to support the participant in developing the best path for achieving the goal specified on the basis of the resources he or she possesses. Coaching sessions serve to build the awareness of the participants, ask questions, and suggest exercises which help to look at a given situation from a different perspective [12]. The International Coach Federation does not indicate the recommended number and duration of coaching sessions, which are agreed on a case-by-case basis with the coachees. Nowadays, coaching sessions may be conducted in different ways, for example during a face-to-face meeting, through Internet tools (such as Skype), by telephone or mixed. The subjects of coaching may be related to multiple areas, such as: professional development, health, management, and work-life balance [10].

The importance of coaching in the context of professional development of employees is indicated by Ramirez-Cyzio, who stresses that career coaching makes it possible to: (1) plan one's own development in deliberate manner, (2) concentrate on the client's resources and values, (3) diagnose the professional situation with reference to both achievements and plans, taking into account the potential advantages and disadvantages [32]. Macieńko lists career coaching amongst the forms of assistance aimed at preventing professional burnout [31]. The positive aspects resulting from the use of career coaching are presented in Table I.

Tab. 1. Benefits of career coaching described in the available literature

\begin{tabular}{|c|c|}
\hline Career coaching & $\begin{array}{l}\text { - } \text { building a development plan }[11,33] \\
\text { - } \quad \text { supporting employees in their development }[10-11,33] \\
\text { - } \quad \text { preventing professional burnout [31] }\end{array}$ \\
\hline
\end{tabular}

Source: authors' analysis based on the available literature indicated in the table.

Palmer et al. describe the potential of coaching in health-related areas, indicating its role in the context of attaining goals and developing healthy behaviours [39]. Donner and Wheeler in the report prepared for the International Council of Nurses (ICN), described the benefits of coaching, such as the support for professional development, the increase in job satisfaction and the strengthening of job retention [38].

The importance of career coaching and mentoring in achieving goals related to professional development, strengthening self-confidence and adapting to the changing healthcare system has been highlighted by Skiem and Brooks [11]. Baek and Jang conducted research verifying 
the effectiveness of a coaching programme amongst nurses concerning: job satisfaction, emotional intelligence, self-efficacy, and coaching skills. The results revealed statistically significant differences in all of the above-mentioned areas to the advantage of the group who had completed the coaching programme [9]. Describing the experiences from the implementation of "The Nursing Career Coaching and Professional Development Program" at Houston Methodist Hospital, Fletcher pointed out an improvement of work-life balance, the achievement of life and professional goals, the satisfaction from the work performed, and the promotion of lifelong learning, as well as underlined the potential of this programme in helping individuals to stay in their profession [10]. A summary concerning the effects of coaching in the context of professional development of nurses is presented in Table 2.

Tab. 2. Benefits of coaching in the context of professional development of nurses, as described in the available literature

\begin{tabular}{|c|c|}
\hline $\begin{array}{l}\text { Coaching in the } \\
\text { professional } \\
\text { development of } \\
\text { nurses }\end{array}$ & $\begin{array}{ll}\text { - } & \text { increased job satisfaction }[9-10,38] \\
\text { - } & \text { reinforcement of self-efficacy and emotional intelligence [9] } \\
\text { - } & \text { achievementenance of a work-life balance }[10] \\
\text { - } & \text { potential support forsional gob retention }[10,38] \\
\text { - } & \text { promotion of lifelong learning }[10] \\
\text { - } & \text { improvement of interpersonal relations and } \\
& \text { communication [38] }\end{array}$ \\
\hline
\end{tabular}

Source: authors'analysis based on the available literature indicated in the table.

\section{CONCLUSIONS}

Significant problems that affect the nursing staff in Poland and other EU states include: failure to take up employment in the profession, low job satisfaction level, professional burnout and resignation from practicing the profession. These non-financial factors can be potentially modified during the coaching process. This approach may help to deliberately create one's own development, and consequently it is worth being considered in building professional development amongst nurses. Furthermore, coaching may help to improve: interpersonal relations, increase the job satisfaction level and prevent professional burnout. Further application research on the effectiveness of coaching for nurses is necessary to explore the determinants of its influence for nurse professional but also for patients' wellbeing and safety.

Financial status of nurses in Poland is another issue beyond the scope of this paper.

\section{REFERENCES/PIŚMIENNICTWO}

1. Ustawa z dnia 15 lipca 2011 roku 0 zawodach pielęgniarki i położnej, Dz.U.2011.174.1039 art. 2, art. 4 i art. 10 b. Pobrane z: https://www.prawo.sejm. gov.pl

2. Lickiewicz J, Piątek J. Doświadczanie agresji w pracy pielęgniarskiej. Sztuka Leczenia. 2014; 3-4, 11-22.

3. Kozłowska L, Doboszyńska A. Mobbing w grupie zawodowej pielęgniarek. Probl. Pielęg. 2012; 20(4): 524-528.

4. Walkiewicz M, Sowińska K, Tartas M. Wypalenie zawodowe wśród personelu medycznego - przegląd literatury. Przegl Lek. 2014;71(5): 263-269.
5. Ostrowicka M, Walewska-Zielecka B, Olejniczak D. Czynniki motywujące i satysfakcja z pracy w wybranych placówkach publicznej i prywatnej służby zdrowia. Zdrowie Publiczne i Zarządzanie. 2013; 11(2):191-209.

6. Lipińska-Grobelny A, Głowacka K. Zadowolenie z pracy a stopień dopasowania do zawodu. Przegląd Psychologiczny. 2009;52(2):181-194.

7. Baruch-Feldman C, Brondolo E, Ben-Dayan D, Schwartz J. Sources of social support and burnout, job satisfaction, and productivity. Journal of Occupational Health Psychology. 2002;7(1):84-93. D0l: 10.1037//1076-8998.7.1.84.

8. Górka E, Kunecka D, Szylińska A, Ptak M. Coaching i mentoring w praktyce pielęgniarskiej. Pomeranian J Life Sci 2019;65(1):98-104. doi: 10.21164/ pomjlifesci.547.

9. Baek M, Jang KS. Development and verification on the effectiveness of coaching program for nurses. Journal of Health Informatics and Statistics. 2016; 41(1):57-66. D0l: https://doi.org/10.21032/jhis.2016.41.1.57.

10. Fletcher $S$. Nurse education specialist utilizing career coaching to encourage lifelong learning. Journal of Nursing Education and Practice. 2016;6(6):71-74. D0l: https:// doi.org/10.5430/jnep.v6n6p71.

11. Skiem PT, Brooks BA. Career coaching 101. Imprint. 2007; 64(1):26-29.

12. International Coach Federation. [Internet]. [cited 2018 August 27]. Available from: https://icf.org.pl/coaching/

13. Gerlach R. Rozwój zawodowy jako element całożyciowego rozwoju człowieka. Polityka Społeczna. 2014; 3(41):3-6.

14. Wołk Z. Rozwój zawodowy na tle życia. Życie człowieka jako proces rozwojowy. Problemy Profesjologii. 2005;1:35-47.

15. Gawroński A. Pojęciowa problematyka kariery zawodowej w kontekście rozwoju pracowniczego. Problemy Profesjologii. 2015; 2:87-97.

16. European Federation of Nurses Association. [Internet]. [cited 2018 August 27] Available from: www.efnweb.org

17. Centrum Kształcenia Podyplomowego Pielęgniarek i Położnych. Analiza wyników egzaminów państwowych przeprowadzonych w sesji wiosennej 2018. [Internet]. [cited 2018 August 08]. Available from: www.ckppip.edu.pl

18. "Analiza liczby zarejestrowanych i zatrudnionych pielęgniarek i położnych w roku 2011 oraz prognoza liczby zarejestrowanych i zatrudnionych pielęgniarek i położnych na lata 2015-2035" [Internet]. [updated April 2013; cited 2018 Jul 15]. Available from: www.izbapiel.org.pl/attachments/article/2010/Analiza\%20 2.03.2015.pdf

19. Hasselhorn HM, Mueller BH, Tackenberg P. Working Conditions and Intent to Leave the Profession Among Nursing Staff in Europe, Stockholm: National Institute for Working Life, Working life research 2003 report, no 7.

20. Radkiewicz P, Widerszal-Bazyl M, Pokorski J, i wsp. Dlaczego pielęgniarki wcześnie odchodzą z zawodu? - Bezp Pr Nauk Prakt. 2004;7 8:31-34.

21. Radosz Z, Paplaczyk M. Zawód pielęgniarka - jakie możliwości mają młodzi absolwenci kierunku pielęgniarstwo Pielęg XXI w. 2017;4(61):31-35.

22. Aiken LH, Sloane DM, Bruyneel $L$, et al. Nurse staffing and education and hospital mortality in nine European countries: a retrospective observational study. The Lancet. 2014; 383(9931):1824-1830. D0I: 10.1016/S0140-6736(13)62631-8.

23. Gajda K, Kózka M, Brzyski P, i wsp. Wpływ struktury zatrudnienia personelu i wybranych czynników organizacyjnych szpitala na wskaźnik zgonów pacjentów hospitalizowanych w szpitalach polskich uczestniczących w projekcie RN4CAST. Zdrowie Publiczne i Zarządzanie - Zeszyty Naukowe Ochrony Zdrowia. 2012; 10(4):296-304, doi:10.4467/208426270Z.13.031.1179.

24. Heinen MM, van Achterberg T, Schwendimann R, et al. Nurses' intention to leave their profession: a cross sectional observational study in 10 European countries. International Journal of Nursing Studies. 2013;50(2):174-84. D0l: 10.1016/j. ijnurstu.2012.09.019.

25. Wysokiński M, Fidecki W, Walas L, i wsp. Satysfakcja z życia polskich pielęgniarek. Probl Pielęg. 2009; 17(3):167-172.

26. Kunecka D, Kamińska M, Karakiewicz B. Analiza czynników wpływających na zadowolenie $z$ wykonywanej pracy w grupie zawodowej pielęgniarek. Badanie wstępne. Probl Pielęg. 2007; 15(2-3):192-196.

27. Kwiecień-JaguśK, WujtewiczM. Analiza obciążenia pracą personelu pielęgniarskiego oddziałów anestezjologii i intensywnej terapii na podstawie polskojęzycznej wersji kwestionariusza japońskiego. Problemy Higieny i Epidemiologii. 2015;96(1):128137.

28. Nowakowska I, Rasińska R. Związek wybranych czynników socjodemograficznych z wypaleniem zawodowym wśród pielęgniarek. Polish Nursing. 2014;1(51):26-33.

29. Aiken LH, Sloane D, Griffiths P, et al. Nursing skill mix in European hospitals: crosssectional study of the association with mortality, patient ratings, and quality of care. BMJ Quality and Safety. 2017;26(7):559-568. D0I: 10.1136/bmjqs-2016-005567.

30. Zelga K. Coaching jako skuteczna forma rozwoju pracowników. Rynek Społeczeństwo-Kultura. 2017;2(23):32-37. 


\section{Coaching in the professional and personal development of nurses}

31. Macieńko M. Profilaktyka wypalenia zawodowego. Innowacje Psychologiczne. Studenckie Czasopismo Naukowe. 2017; 6(1):64-68.

32. Ramirez-Cyzio K. Career coaching - podstawy teoretyczne i praktyka. Coaching Review. 2010; 2(2):19-34.

33. Szejniuk A. Coaching - narzędzie rozwoju kompetencji zawodowych. Journal of Modern Science. 2015; 3(26):73-86.

34. Kaniewska E, Stawny P. Satysfakcja zawodowa pracowników sektora ochrony zdrowia. Pielęg Pol. 2012;2(44):81-84.

35. GrafL, Śleziona M, Ptaszek G, Stołecka B. Wpływ rozwoju zawodowego na wizerunek pielęgniarstwa. Pielęgniarstwo Specjalistyczne. 2014;4(1), 171-176.

36. Tomaszewska M, Cieśla D, Czerniak J, Dykowska G. Możliwości doskonalenia zawodowego pielęgniarek - potrzeby a rzeczywistość. - Probl Pielęg. 2008;16(12): 40-47.

37. Brzeziński Ł. Coaching narzędziem rozwoju zawodowego pracowników. Problemy Profesjologii. 2013; 17(2):113-124.

38. Donner GJ, Wheeler M. Tłumaczenie: Małgorzata Kisilowska. Mentoring i coaching w pielęgniarstwie. Przewodnik [Mentoring and coaching in nursing. A guide]. [updated 2018; cited 2018 August 20]. Available from: http://www.ptp.na1.pl/pliki/ pdf/ICN_Mentoring_i_coaching_w_pielegniarstwie_Przewodnik.pdf

39. Palmer S, Tubbs I, Whybrow A. Health coaching to facilitate the promotion of healthy behaviour and achievement of health-related goals. International Journal of Health Promotion and Education. 2003;41(3):91-93. D0I: 10.1080/14635240.2003.10806231.
Manuscript received: 12.09.2019

Manuscript accepted: 11.02.2020

Translation: TRANSLA PROJECT. Tłumaczenia specjalistyczne. Tomasz Weiss 